\title{
EFICIÊNCIA NA DETECÇÃO DOS VÍRUS PLRV, PVX E PVY EM TECIDOS VEGETAIS DE GEMA APICAL DORMENTE MAIS ESTOLÃO, BROTOS E FOLHAS DA BATATA, PELO MÉTODO SOROLÓGICO ENZYME-LINKED IMMUNOSORBENT ASSAY-ELISA
}

\section{DETECTION VÍRUS PLRV, PVX E PVY EFFICIENCE ON POTATO TISSUES FROM TUBER END, STOLON END, SPROUTS AND LEAVES BY THE SOROLOGICAL METHOD ENZYME-LINKED IMMUNOSORBENT ASSAY-ELISA}

\author{
Milton Vasconcelos GUEDES \\ Orientadora: Professora Dra. Maria Lúcia Rosa Zaksevskas da Costa LIMA \\ Departamento de Fitotecnia e Fitossanitarismo
}

\begin{abstract}
RESUMO
A propagação vegetativa da batata (Solanum tuberosum L.) é a causa da degenerescência de variedades uma vez que o tubérculo-semente utilizado no plantio pode perpetuar os vírus incidentes na planta-mãe. Daí a necessidade de renovação constante de estoques de batata-semente, bem como, de se obter técnicas eficientes de diagnóstico. Os objetivos gerais deste trabalho foram (1) comparar a eficiência na detecção dos vírus PLRV, PVX e PVY por meio do teste sorológico DAS-ELISA em tecidos vegetais de diferentes origens:- da gema apical + estolão, brotos e folhas, após quebra natural de dormência, das variedades Baraka, Contenda e Elvira; (2) verificar a confiabilidade da detecção de vírus em tecidos vegetais dormentes ou récem-brotados, visando reduzir o tempo de obtenção dos resultados em relação ao uso de folhas. Os objetivos específicos foram: avaliar a incidência dos diferentes vírus em amostras de campos de batataconsumo, na segunda geração de multiplicação; comparar os resultados obtidos com o equipamento de leitura de ELISA e os da leitura visual. A homogeneidade das variâncias dos tratamentos foi testada pelo teste de Bartlett e a comparação das médias dos tratamentos foi feita utilizando-se o teste de Tukey, ambos ao nível de $5 \%$ de probabilidade. Os resultados foram analisados utilizando-

se o programa estatístico MSTATC, versão 2.11. A incidência média das diferentes viroses nas amostras das variedades Baraka, Contenda e Elvira, foi maior para PVY e PLRV, e muito baixa para PVX. O PVY foi o vírus de maior incidência nas três variedades: 14,1\% em Baraka, 10,9\% em Elvira e 2,9\% em Contenda. O PLRV ocorreu com incidência de 3,6\% na variedade Elvira, 2,3\% em Baraka e 0,7\% em Contenda. O PVX foi detectado em níveis inferiores a $0,5 \%$ nas três variedades; a variedade Contenda foi a que apresentou os menores índices médios de incidência para os três vírus, quando comparados às demais variedades estudadas; o teste DAS-ELISA pode ser utilizado na detecção dos vírus PLRV e PVX, tanto em gema apical dormente + estolão, como em brotos ou folhas, após quebra natural de dormência nas variedades Baraka, Contenda e Elvira; a eficiência do teste DAS ELISA pode variar de acordo com a origem do tecido vegetal utilizado; o vírus PVY, não pode ser detectado com segurança na gema apical dormente + estolão, para as três variedades testadas. Tendo em vista os resultados apresentados pode-se concluir que a detecção das viroses em brotos foi mais eficiente para todas as variedades estudadas antecipando-se os resultados e proporcionando um ganho de no mínimo 30 dias.
\end{abstract}

\begin{abstract}
The vegetative propagation in potatoes (Solanum tuberosum L.) is the cause of varietal degenerescence, once seed tubers from infected mother plants may carry viruses. Therefore, there is a need for constant seedstock renewal, as well as reliable diagnostic techniques. The general objectives of this work were (1) compare the detection efficiency for PLRV, PVV, and PVX under the DAS-ELSA serological test in plant tissues of different origens, tuber end + stolon end, sprouts and leaves, alter natural break of dormancy from 'Baraka', 'Contenda', and 'Elvira'; (2) verify the reliance of virus detection dormant, or early sprouting tissues in relation to caves, as a matter of time saving to obtain results. Specific objectives were: assess the different viruses incidences in second generation tubers from ware potato fields; compare results from electronic and visual readings in DAS-ELISA tests. Homoscedasticity was tested using the Bartlett test, and mean treatment comparison was done using the Tuckey test, both at $5 \%$ probability level. Results were analyzed using MSTATC statistical program, version 2.11. The mean incidence of PVY

and PLRV in 'Baraka', 'Contenda', and 'Elvira' was greater than the mean incidence of PVX. PVY had the highest incidence in all three cultivars: $14.1 \%$ : 10.9, and 2.9 for 'Baraka', 'Elvira', and Contenda, respectively. PLRV incidences were, 3.6\%, 2.3\%, and $0.7 \%$ for 'Elvira', 'Baraka', and 'Contenda', respectively. PVX was detected with levels below $0.5 \%$ for all 3 cultivars. 'Contenda' presented the lowest incidence for all viruses, as compared to the other cultivars studied. DAS-ELISA could be used to detect PLRV and PVX either in dormant tuber end + stolon end, on in sprouts, or in leaves, after natural break of dormancy, of 'Baraka', 'Contenda', and 'Elvira'; the reliance on DAS-ELISA results may change depending on the sample source used; PVY could not be safely detected from tuber end + stolon end samples, for the three studied cultivars. In conclusion, based on the obtained results, it can be said that: detection of viruses in sprouts was more efficient and reliable for all the studied cuitivars, representing a 30 day gain in time to obtain the results.
\end{abstract}

